After leaving Shepton Mallet, on the right hand side of the Bath road, an interesting section was seen, where on the upturned edges of the Carboniferous Limestone are horizontally deposited beds of Rhætic and Liassic age. This succession is due to one or more faults which have brought the Liassic beds on a level with the Carboniferous limestone, against which the former rest at a slight angle. These Liassic beds, which are unmistakeably the same in geological age as the Weston beds near Bath, and contain the usual Lower Lias fossils, assume a precisely similar appearance to the "Sutton stone" beds at Southerndown," and both lithologically, and as regards their fossil contents, at once presented to those members who had joined the Southerndown excursion, a striking resemblance, if not perfect identity, - the first few blows of the hammer revealed the usual fossils, Lima gigantea, L. punctata, etc., of the Lower Lias, and many specimens of Ostrea liassica. The same bed was traced on rising ground the other side of the road. The chief peculiarity noticeable in this, as compared with the "Sutton stone" series, was the absence of corals, of which during this short visit no traces could be found. Even the very flinty conglomerates, which form so conspicuous a feature in the beds at Southerndown, are traceable here. The members then mounted the axis of the Mendips, and followed the Romano-British Road, called the "Ridgway," till they arrived at the Beacon, one of the highest points. Whilst passing along the Ridgway, several indications of Trap were noticed, especially one in an adjoining field, where Mr. Moore pointed out this rock cropping out in the form of a boss, thus giving evidence of a mighty volcanic movement which took place at a remote period, the limestone, before horizontal, being then upheaved by this great protuding mass, and thrown off on either side with considerable force; the lava at the same time bursting forth wherever a vent could be found. The approximate time of this upheaval must have been after the deposition of the Coal-measures. For in the Valley to the north, the older rock overlies the more recent strata, and coal is worked beneath the Carboniferous limestone, which Mr. Moore accounted for by the great force of the upheaval doubling the strata thus back upon itself. The recent discovery of the Trap rock in this neighbourhood adds weight to the theory.

H. H. W.

\title{
OOREFSPOINDEINCF.
}

\section{PROF. J. BEETE JUKES' REPLY TO MR. G. POULETT SCROPE'S ARTICLE.}

\section{To the Editor of the Geological Magazinz.}

SIr,-I am unwilling to allow Mr. Poulett Scrope's article in your last number to pass sub silentio, and therefore seize the first halt that occurs to me, since receiving it, to pen a few words in reply to it.

1 See paper by Mr. E. B. Tawney-Gzol. MsG., January, 1866, p. 39. 
First let me acknowledge my own debt of gratitude to Mr. Poulett Scrope, whose clear exposition, more than thirty years ago, of the purely subaerial origin of the valleys of Central France has had, perhaps, even more influence on my mind than I was altogether conscions of, in leading me to correct views of the amount of the action of atmospheric forces. I used, indeed, to suppose that this was an exceptional case, or one applicable only to soft Tertiary rocks and thin lava streams, till my investigations into the origin of the river valleys of the South of Ireland showed me that it was ondy a normal example of a universal rule.

The subject of the production of the "external form of the ground" is one which has been so little discussed, that it is difficult to write on it without being misunderstood.

By the "form of ground" I would mean, not its altitude above or below the level of the sea, still less the position, (horizontal, inclined, bent or broken) of the rocks composing it,-lout simply the form of its external surface : and I think Mr. Poulett Scrope will agree with me that internal forces have never any direct effect upon that, except to a slight extent and only for a brief period of time.

Even a volcanic cone could not stand ten years without having its sides more or less washed or gullied by rains, abraded by winds, or modified in some way and to some extent, however slight.

The direct effects of earthquakes in cracking, or bending the surface, are surely very insignificant, and the features thus produced are externally modified almost as soon as they are made.

Great elevation and depression of land might occur, and apparently has occurred, without any alteration of "the form of the ground," though of course some change of slope about the boundaries of areas thus acted on must be produced even at the surface.

I hope Mr. Poulett Serope will pardon me if I say that I do not know whether "the basin of Switzerland" be "a synclinal valley between the elevated ridges of the Alps and Jura" or not. Still more ignorant am I of the Italian side of the Alps, a region I can never hope to visit till the Geological Survey of Ireland is finished, and long before that time I shall probably myself be passing into the inorganic condition.

The hills in the central valley of Switzerland are, I believe, "hills of circumdenudation :" that is, are hills solely because of the removal of the matter which once surrounded them.

The hills of the Jura and the Alps are, doubtless, "hills of uptilting," that is, the rocks composing them are at that altitude and in that position in consequence of having been thrust up by forces acting from the interior. But the rocks which we now see at the surface were not at, or near, the surface at the time they were thus thrust up.

The present surface cuts across the edges of beds having an aggregate thickness of many thousand feet. If that surface was formed before the rocks were disturbed and while they were still horizontal, there must have been an excavation in order to form it, sufficient to show a section of that depth, and the subsequent elevation must have been confined to that previous hollow. 
No one would uphold such an idea.

It follows then that while the beds were being tilted up, or since they have been tilted, a sufficient mass of rock has been removed to allow of the edges of some beds appearing at the surface that were once buried many thousand feet below it.

In other words, the present surface of the ground has been gradually arrived at by the external removal of vast masses of rock that previously covered it.

It makes no difference whether the surface be a perfect plane or a corrugated mountain chain, wherever beds crop to the surface, it can only be the effect of denudation.

A plain formed across the edges of a great series of beds, shows that either from length of time or other circumstances the external denuding force has completely obliterated the effect of the action of elevation.

A mountain chain shows that along a certain band of country the action of elevation has been so great, or so long continued, that the forces of denudation have not been able to overcome it.

The mountains still stand in spite of the denudation, although probably it has been much greater there than in the surrounding regions, and therefore the most deeply-seated rocks have succeeded in reaching the surface there.

In every case the "form of the ground," whether in mountains, hills, valleys, or plains (except those so recently made that there has been no time to modify it), is the result of external action upon materials variously prepared and placed for it by internal force.

I should suppose that the Alps must have concealed in them one or two or more old surfaces, on which the superior formations repose uncomformably. Whether it will ever be possible to distinguish these I do not know, but it must be done before the structure of the mountains can be understood, or their history be unravelled. Careful sections, on a true scale, with nothing inserted that cannot be actually seen, must also be constructed before we can be said to be in possession of even sufficient data to state the problem of Alpine geological history.

Lastly, allow me to say that I feel sure there is no real difference between Mr. Poulett Scrope and myself in our opinions on this subject, and that any apparent difference arises from the want of a precise settlement of the meaning of terms.

\section{J. BEETE JURks.}

P.S. There is one passage in Mr. Mackintosh's letter on which I may usefully make a remark, and that is at page 282 , where he speaks of the Old Red Sandstone of Herefordshire as more easily eroded than the Carboniferous Limestone. The Old Red Sandstone of Cork and Kerry, however, is much harder than that of Siluria, the shales being all converted into hard clay-slates by true slaty cleavage. Many parts of the Old Red of the south-west of Ireland indeed are lithologically very like parts of the Cambrian rocks of North Wales and Wicklow.

Gilronan, Arran Island, Gauway Bax, June 11th, 1866. 